\title{
The domesticated Absurd
}

\author{
FANNY LACROIX*
}

\begin{abstract}
In this article, translation, linguistics, philosophy and cultural studies meet in order to discuss the translation of Absurdist theatre. The aim of this discussion is to determine whether the universal and philosophical message conveyed by most Absurdist plays is accurately rendered in translation. Although the Theatre of the Absurd expresses absurd thoughts through absurd language, it is not meaningless, but on the contrary seeks to make people aware of the anguished purposelessness of human existence. It is therefore essential that translations of Absurdist plays render this message in the target language in an equally absurd, yet meaningful way. Since all Absurdist plays cannot be taken into account in the scope of this article, a case study will be carried out, using Eugene Ionesco's play La Cantatrice Chauve as focus. An evaluation of its English translation by Donald M. Allen, The Bald Soprano, is carried out in order to identify its strengths and weaknesses. Suggestions are made where relevant to enhance the translation or comment on its level of success.
\end{abstract}

Keywords: Theatre of the absurd, translation, Eugene Ionesco,

Disciplines: Translations studies, linguistics, philosophy, cultural studies, French and English.

\section{Introduction}

Literary translation encompasses a variety of texts, from novels to poetry, from short stories to theatre plays. The translation of each genre may present challenges in terms of content, form and culture. This paper focuses on the translation of Absurdist Theatre, because of one specific characteristic. The topic of predilection of Absurdist playwrights - the meaninglessness and precariousness of human existence - has been widely dealt with in other literary genres, but this article focuses on Absurdist Theatre because of the way in which it deals with the topic. Indeed, the Theatre of the Absurd is characterised by a devaluation of language and privileges - "the open abandonment of rational devices and discursive thoughts" (Esslin, 1961: 24), which may result in dialogues consisting of "incoherent babblings" (Esslin, 1961: 22). In this case, one may be justified in asking how one can translate what does not make sense.

* School of Languages, Vaal Triangle Campus, North-West University. Email: Fanny.Lacroix@nwu.ac.za 
It is obviously not impossible: it is enough to browse the shelves of bookshops to see that translations of Absurdist plays have been carried out in different languages. It would however be interesting to look at how successful these translations are.

But since it is not possible to evaluate the whole of the Absurdist corpus within the scope of this article, the focus will fall on relevant extracts from La Cantatrice Chauve (1950), written in French by Romanian-born author Eugène Ionesco, and from The Bald Soprano (1958), its British English translation, by Donald M. Allen. This play was selected because of the almost organic way in which the play grew after Ionesco attempted to teach himself English. In his Préface to La Cantatrice Chauve, Emmanuel Jacquart (1993b: 9) describes the creation of the play as an unconscious process and quotes Ionesco as saying:

Un phénomène bizarre se passa, je ne sais comment: le texte se transforma sous mes yeux, contre ma volonté [...].

This phenomenon, which is reminiscent of the surrealist creative process called "automatic writing", echoes Esslin's statement about "the open abandonment of rational devices and discursive thoughts", that is characteristic of the Theatre of the Absurd and makes La Cantatrice Chauve a particularly interesting play to study, and a challenge to translate.

The challenge is due to the fact that, although the play was written in French, it features British characters: the Smiths, their servant Mary, the Martins and a fire chief, whose interaction throughout the play does not follow any plot and appears utterly nonsensical.

The translation of La Cantatrice Chauve is therefore evaluated in terms of domestication and of how well it conveys the absurd. In order to do so, textual, intertextual and extratextual aspects of the translation are analysed.

This article argues that, although mostly successful, Allen's translation would have benefited from further domestication in some instances, in order for the meaning to be conveyed even more accurately.

The first part shows that Absurdist Theatre indeed makes a philosophical statement and explains why it is important to take it in consideration when translating Absurdist plays. The second part focuses on the strengths of the translation as far as the as the elements mentioned above are concerned, while the third part focuses on the weaknesses of the translation and makes suggestions to improve them, again in relation to the same elements.

\section{The meaning of the absurd}

The following definition of the Theatre of the Absurd, taken from the Penguin Dictionary of Theatre, is to be found as quoted by Hinchliffe in The Absurd:

In The Penguin Dictionary of Theatre (1966) John Russel Taylor writes: Absurd, Theatre of the. Term applied to a group of dramatists in the 1950s who did not regard themselves as a school but who all seemed to share certain attitudes towards the predicament of man in the universe (Hinchliffe 1977: 1). 
This predicament can be defined as anguish produced by awareness of the fact that man's existence is purposeless, and is the central theme of Absurdist theatre.

This view is shared by Esslin (1980: 402) in The Theatre of the Absurd: the Theatre of the Absurd is intent on making its audience aware of man's precarious and mysterious position in the universe.

Taylor's (1977: 1) definition adds that this concern is expressed through the abandonment of "logical construction, of the rational linking of idea with idea in an intellectually viable argument" and that instead, "the irrationality of experience is transferred to the stage".

La Cantatrice Chauve is full of these occurrences, like the verbal joust between the Smiths and the Martins in scene XI, on which the play ends. In this scene, the tension rises between the Smiths and the Martins, as they first exchange parodies of proverbs and social clichés to finally yell nonsensical phrases at each other. The utterances of the characters are incoherent, do not relate to each other in any way, nor do they to the situation, and contribute to a rising tension between the characters, which ends in chaos.

These definitions show that Absurdist plays, although based on irrational situations, are not absurd where meaning is concerned. True, the situations depicted may not make any sense to the audience, because of the discrepancy between language and what is going on on stage, but one may argue that the language is clearly recognisable as either French or English. Absurdist authors have not created a language of their own. The Absurd actually arises from semantics and stage dynamics.

However, one cannot deny that the language used in the Theatre of the Absurd breaches the Gricean maxims of quality (truth), quantity (information), relation (relevance) and manner (clarity), to such an extent that the audience becomes confused. The unusual collocations and the irrationality of the relationship between language and situation are what cause the feeling of absurdity. However, what Esslin refers to as a "devaluation and disintegration of language" (1980: 406) illustrates the breakdown of society and communication between people, which is the philosophical message Absurdist authors seek to convey to their audiences.

Thus, the Theatre of the Absurd does not present its audience with nonsensical dialogues and situations for its own sake. Although the characters' actions and utterances are completely devoid of motivation and meaning in relation to the situation in which they are taking place, there is a reason for this. The author seeks to make audiences aware, through language and art, of the breakdown of our society and, from a more existentialist point of view, of the purposelessness of human existence and its resulting anxiety.

La Cantatrice Chauve, by depicting the utterly nonsensical interaction of the Smiths and their guests, may be said to strongly convey this meaning. The circumstances in which Ionesco found the inspiration for the play are also of interest. Indeed, as Hervey \& Higgins (2002: 59) state, the author's attitude to the subject matter and his intention regarding the effect of the text on his audience, are important issues in translation.

In his 1993 preface to La Cantatrice Chauve, Emmanuel Jacquart quotes Ionesco explaining that he wrote the play after trying to learn English 
using a self-teaching method. He marvelled at the platitudes and commonplace statements contained in the language's corpus.

These kinds of statements are typical of old-fashioned language methods, in that they are meant to provide a real-life background to the use of idiomatic expressions, grammatical structures and vocabulary. This provided the author with the material required for his play, as he realised that his ambition was to communicate to his contemporaries the essential truths of which his language manual had made him aware (Jacquart, 1993b:8). Due to the method Ionesco was using, the statements created illogical situations, such as when one of the characters, Mrs. Smith, informs her husband, Mr. Smith, that they live in the London area, that they have three children, and so forth.

The result of this ambition was La Cantatrice Chauve, which Ionesco describes as an "anti-pièce, c'est-à-dire une vraie parodie de pièce" (Jacquart, 1993b: 11), because it defies the traditional rules of drama, originally prescribed by Aristotle as the law of non-contradiction, the principle of causality and the factor of continuity (Hinchliffe, 1977: 56). This is characteristic of most of Ionesco's work, together with the simple plot, dehumanised characters and absurd (if logically so) language (Hinchliffe, 1977: 59).

Although it seems Ionesco was not concerned with ideology at the initial stage of the creation of the play (Jacquart, 1993b: 10-11), his plays, including La Cantatrice Chauve, cannot be regarded as mere entertainment. Hinchliffe explains:

Ionesco is not committed to artistic definitions, nor to political or religious codes; but neither can his plays be mere entertainment (1977: 61).

The above substantiates the statement made at the start of this paper, which says that Absurdist Theatre reflects a philosophical position translated into literature. Hervey \& Higgins can also be quoted in their exposition of French-English translation. They identify five textual genres: empirical, philosophical, religious, persuasive and literary, but also acknowledge the existence of hybrids, i.e. texts which present characteristics belonging to two, or more, of the aforementioned genres (2002: 59-61). Since the fact that La Cantatrice Chauve is a play with a philosophical message has been highlighted, it may be considered as a philosophical-literary hybrid, and it is helpful to keep this in mind when evaluating Allen's translation.

It may therefore be concluded that, since the Theatre of the Absurd in general, and more specifically La Cantatrice Chauve, is known to serve a philosophical purpose - namely, that man's position in the universe is precarious and meaningless ${ }^{1}$ - the target text should reflect the same intention, in the absence of a translation brief giving different or contrary instructions. ${ }^{2}$ This is taken into account in the next two sections, which

1. The play also offers a social commentary, but this is not taken into consideration in this paper.

2. The translation brief dictates the way in which the source text will be translated. According to it, the translator will decide which translation method to use, and will have to make decisions as to how to render the contents and the form. 
deal with the weaknesses and the strengths of Allen's translation of $\mathrm{La}$ Cantatrice Chauve.

\section{The strengths of the translation}

This section deals with the strong points of the translation, in terms of how well it domesticates the absurd.

The translation strategy is key in the process of translation, as it may greatly influence the finished product. There are many strategies for a translator to choose from depending on what is required by the client and the translation brief. According to Jeremy Munday, Absurdist plays are generally domesticated in translation (2007), which means that they are adapted to the requirements of the target culture and language. Chesterman \& Wagner point out that nothing should be left that links the text specifically to the source culture, perhaps not even proper names (2002: 58). Foreignisation, on the contrary, consists of respecting the source text

by disrupting the cultural codes that prevail in the target language (Venuti, 1995: 20).

By using this method, the translator allows the reader to get a sense of the linguistic and cultural differences between his own language (the target text) and that of the source text.

Of course, it is possible to work in both directions, as Fawcett confirms (1997: 116), and the translator's choice between both methods is likely to depend very much on the translation brief, including the type of target readership, as well as on the type, variety and genre of the text to be translated. For instance, foreignisation would be relevant in a situation where the idiosyncrasies of the source text must be highlighted.

Just as for all translations, the translation brief plays an important role in the way the translation is processed. The translation brief, which Vermeer refers to as skopos, includes the aim and mode of the translation (Vermeer, 2004: 227). This will have an influence on the way the translation is performed. For the purpose of this study, we will assume that the translation of the Absurdist play in question, La Cantatrice Chauve, was commissioned in order to allow target language readers to access the written text in their own language. The target readership is paramount when one considers the best translation strategy for any text, but maybe even more so as far as a theatre play is concerned. As Marta Mateo puts it:

(A) drama performance would not exist without an audience, and a translation depends - for its success and indeed for its very existence as a translation - on the interests and cultural assumptions of the receiving system (1995: 99).

This analysis of the translation's strengths focuses on scene XI, which would have required extensive domestication due to the textual, intertextual and extratextual aspects of the source text. The textual aspect is related to the importance of style in terms of translating scene XI. The translator also had to deal with the issue of intertextuality, when a quote from another play appears in the text, as well as with extratextual 
aspects such as the translation of proverbs.

Scene XI depicts a nonsensical and increasingly tense argument between the Smiths and the Martins. As the tension rises, their parodic exchange of proverbs and clichés give way to increasingly absurd statements, characterised by alliteration, assonance and rhyme. These elements actually contribute to the creation of a highly-charged atmosphere (Jacquart, 1993a: 147). The section of the play starting with Mr Smith repeating the word "Kakatoes" (Ionesco, 1954: 98) ten times and ending with Mr. Martin saying "De l'ail à l'eau, du lait à l'ail" (Ionesco, 1954: 99), is likely to represent quite a challenge for the translator - specifically for the reasons mentioned above.

However, it can be said that the translation of this section was carried out successfully in terms of domestication, because it retains the effect of rising tension created in the source text, while adapting the contents to the target culture when relevant. The examples and comments provided below confirm this point.

This section of Scene XI contains many instances of alliteration, assonance and rhyme from the beginning to the end. For example, a [k] alliteration is to be found in "Quelle cacade!", "Quelles cascades de cacades!", "Cactus, coccyx! cocus! cocardard! cochon!" (Ionesco, 1954: 96), "Les cacaoyers des cacaoyères donnent pas des cacahuètes, donnent du cacao" (Ionesco, 1954: 97). "Les souris ont des sourcils, les sourcils n'ont pas de souris" (1954: 97) features an [s] alliteration, together with an [i:] assonance. A rhyme in [u:?] occurs in several lines, from Mrs Martin's "Touche pas ma babouche" to her "Sainte Nitouche touche ma cartouche" (Ionesco, 1954: 98)

In this section, it may be argued that the style is more important than the content. If one looks at the examples which feature a [k] alliteration, it seems evident that the words were chosen for their alliterative properties as opposed to their meaning. True, these sentences are grammatically and syntactically correct, but their absurdity lies in the fact that, semantically, they are not coherent with any of the other utterances in this section, or cohesive within the situation. It is also important that the alliteration and assonance should be rendered in the target text because they greatly contribute to the expression of growing tension between the four characters present in Scene XI (Jacquart, 1993a: 147). For example, Allen translated the statement uttered by Mrs Martin, "Les cacaoyers des cacaoyères donnent pas des cacahuètes, donnent du cacao" (Ionesco, 1954: 97) as "Cacao trees on cacao farms don't bear coconuts, they yield cocoa" (1958: 40). The word "coconut" is substituted for the word "cacahuète", which means "peanut" in English, as the word "peanut" does not allow for [k] alliteration with the rest of the sentence. In this case, not only has the alliteration been respected throughout the sentence, but the meaning has been retained too, but for one word, which does not compromise the quality of the translation as its meaning is of secondary importance to the alliteration.

Since conveying the effect the text has on the target reader depends on

3 "From garlic to water, from milk to garlic" (Author's literal translation). But translated as "From sage to stooge, from stage to serge" in The Bald Soprano. 
the alliteration, the latter should be the focus of the translation. Therefore, the translator kept to the source text's alliteration whenever possible, and otherwise resorted to a [u:] assonance, which is close to the original. The resulting effect is one that is indeed very close to that created by the original, due to the fact that the alliteration has been respected, as well as the fact that the incoherence and absurdity of the content were retained through the domestication method. The target reader will therefore also experience increasing tension in this section of the scene. This is essential as this is the last scene, the play therefore ending with unresolved conflict.

It could therefore be said that the form, more than the content, of Scene XI contributes to creating an increasingly tense atmosphere between the Smiths and the Martins. Despite the fact that Allen's translation often distances itself from the source text in terms of contents, it is successful in conveying this highly-strung atmosphere in the target text by conforming to the style of the source text. Indeed, the alliteration and the accumulation of repetitions contribute greatly to the rising tension between the characters.

The verbal joust between the Smiths and the Martins does not only include alliteration, assonance or rhyme. A parodied quotation from a poem by Sully Prudhomme ${ }^{4}$, a $19^{\text {th }}$ century French author, entitled Le Vase brisé (1865) introduces intertextuality as an extra challenge for the translator. Le Vase brisé ends on the following verse: "Il est brisé, n'y touchez pas" (Jacquart, 1993a: 149). Ionesco changed this verse to " $N$ ' $y$ touchez pas, elle est brisée" (1954: 98), where the French "elle" refers to an object of feminine gender as opposed to the "il" of the original, which refers to a masculine object. This instance of intertextuality should be recreated in the target text in order to achieve the same effect of recognition of another text amongst target readers. Allen uses "Who'd stoop to blame?... and I never choose to stoop" (1958: 40), two respectively incomplete and slightly modified sentences taken from different verses of My Last Duchess, a poem by Robert Browning, ${ }^{7}$ and brought together into one single line in The Bald Soprano.

The name of Sully Prudhomme is used together with the name of François Coppée, ${ }^{8}$ another $19^{\text {th }}$ century French author. Although their names are mismatched by the characters as "Coppée Sully" and "Prudhomme François" (Ionesco, 1954: 98), they are clearly recognisable. It is interesting to note that in his translation, Allen replaces the names of François Coppée and Sully Prudhomme with the names of Robert Browning and Rudyard Kipling, both English authors and poets, who were contemporaries of Prudhomme and Coppée. These names will certainly be more easily identifiable for an English audience than Sully Prudhomme or François Coppée would.

The two preceding sections show that the La Cantatrice Chauve presents the translator with challenges of a different nature, textual and

\footnotetext{
$4 \quad 1839-1907$

5 It is shattered, do not touch it (Author's translation).

6 Do not touch it, it is shattered (Author's translation)

7 1812-1889

$8 \quad 1842-1908$
}

TD, 5(1), July 2009, pp. 105-122. 
intertextual, where domestication is concerned. Another challenge the translator will have to face in this play is extratextuality.

In order to provide a successfully domesticated translation, the translator must reckon with the "false" proverbs used in scene XI.

The scene is based on clichés, common place statements and proverbs which the author encountered while teaching himself English (Jacquart, 1993a: 146). The difficulty in translating this kind of language lies therein that it is narrowly linked to the source culture and must therefore be adapted to the requirements of the target culture. Indeed, according to Hervey \& Higgins, it is "a crucial fact that translating involves not just two languages, but a transfer from one whole culture to another" (Hervey \& Higgins, 2002: 31, italics in the text). The translator also faces a technical challenge in the sense that this kind of language often resorts to rhyme or other kinds of linguistic parallelisms. Even though the language is absurd in the context of the dialogue and the situation created on stage, it is not meaningless. The "false proverbs and clichés" have meaning, and a translator has to choose which aspects of the source text he wants to retain: the meaning, the sound, the parallelisms, or any other present.

Some of these "false proverbs and clichés" are based on existing ones, which Ionesco has modified in order to obtain an effect of parody (Jacquart, 1993a: 145). This is supposed to surprise the reader and provoke laughter. For instance, the French reader will recognise that the well-known French proverb "Qui vole un oeuf vole un boeuf" which is mimicked in the deformed proverb "Celui qui vend aujourd'hui un boeuf, demain aura un oeuf"10 (1954: 93). Ionesco also makes use of unjustified comparisons: "On marche avec les pieds mais on se réchauffe à l'électricité ou au charbon"11 (1954: 93); maxims that are irrelevant in the context: "Il faut toujours penser à tout"12 (1954: 93); parody of cliché: "Quand je dis oui, c'est une façon de parler" ${ }^{13}$ (1954: 93); and aphorism: "Prenez un cercle, caressez-le, il deviendra vicieux"14 (1954: 93) (Jacquart, 1993: 146).

Proverbs and aphorisms can be problematic to translate, because they relate to culture. Since the French proverb "Qui vole un oeuf vole un boeuf" has a direct English equivalent, it makes sense that this equivalent be used in the translation, provided that it is also mimicked. The target reader should be able to recognise the original proverb behind it, as is the case in the source text. The only effect which is not rendered in the translation is the rhyme between "boeuf" and "oeuf". However, it may be argued that the rhyme, although it may facilitate recognition and memorising of the French expression, is not essential in English, as the proverb can still be easily recognised under its absurd disguise.

9 He that steals an egg, will steal an ox (One of several English equivalents)

$10 \mathrm{He}$ who sells an ox today, will have an egg tomorrow (Author's literal translation).

11 One walks with one's feet, but one warms up with electricity or coal (Author's literal translation).

12 One always has to think of everything (Author's literal translation).

13 When I say yes, it is a way of speaking (Author's literal translation).

14 Take a circle, stroke it, it will become vicious (Author's literal translation). The reader will recognise the aphorism "vicious circle" in this parody). 
This section shows that the extracts used for the purpose of this analysis have been successfully domesticated. Indeed, the textual, intertextual and extratextual aspects were skilfully adapted to the requirements of the target language and culture. The following section, on the other hand, focuses on the weaknesses of the translation and suggests possible alternatives.

\section{The weakness of the translation}

It can justifiably be argued that all translations have weaknesses and that it is always possible to suggest alternatives, due to the teleological nature of translation (Mateo, 1995: 99). This section shows that improvements are possible, both at textual and extratextual level.

As it is the case in the section on strengths, the evaluation is based on selected extracts relevant in terms of textuality and extratextuality.

From a textual point of view, several mistranslations have been identified. Two examples are given below. The first one is uttered by Mrs Smith in Scene I. In this scene, Mr and Mrs Smith are at home and exchange both nonsensical information and information that is so obvious it shouldn't even be worth mentioning. For instance, Mrs Smith tells her husband that they are called Smith, that they live in the London area, and what they have just had for dinner. Potatoes were on the menu and Mrs Smith declares: "Je ne les aime que lorsqu'elles sont bien cuites" 5 (Ionesco, 1954: 42), which means that Mrs. Smith only likes potatoes when they are well done. However, the target text reads as follows: "I do not like them when they are well done" (Allen, 1958: 9), which says the exact opposite. Beside being a mistranslation, it does not reflect the fact that Ionesco wrote his play using structures reminiscent of those to be found in foreign language self-teaching methods like the one Ionesco used to teach himself English. Ionesco may have used the utterance "Je ne les aime que lorsqu'elles sont bien cuites" (1954: 42) in order to illustrate a grammar point on the French structure "ne ... que", which means "only" in English. It is important that the target language should reflect this, since the way in which Ionesco wrote the play has been established as contributing to the expression of the absurd. "I like them only when they are well done" is thus more accurate.

The second example of mistranslation occurs twice, in similar sentences. However, only the first instance is mentioned here, as the following considerations are valid for the second mistranslation as well.

"This room, with the bed and the green eiderdown is at the end of the corridor, between the W.C. and the bookcase, dear lady!" (1954: 18).

The problem concerns the use of the word "bookcase" as the translation for the French original "bibliotheque". Although correct from a lexical point of view, it is not accurate in the present context. Indeed, "bibliothèque" refers to both a bookcase and a library. So when Mr Martin talks about his bedroom being situated between the W.C. and the "bibliothèque", he is more likely to refer to it as a room between two other rooms, and not a room between a piece of furniture and another room.

15 I like them only when they are well done (Author's translation) 
One may argue that it may very well be a bookcase, which could be possible, especially in the realm of the absurd, but in this scene the absurd is expressed not so much through the breakdown of language than through the aberrant situation of a married couple, who have arrived together at their friends' house, suddenly suffering from amnesia and behaving like complete strangers. Therefore, I suggest that "library" might be a more accurate translation. Indeed, they do not cause the aberrant situation depicted above to lose its nonsensicality.

It may be argued that the above mistranslations do not, however, represent a hurdle to the conveying of the absurd. Indeed, they do not cause the aberrant situation depicted above to lose its nonsensicality: the target still shows Mr and Mrs Martin as unable to recognise each other, although they have been married for years and have arrived at the Smiths' house together. However, since the source text here does not require any extensive domestication between French and English, it is not necessary to localise extensively in the target text.

Apart from the illogical relationship between the dialogues and the situations, a few instances of abrupt drop in language register contribute to the feeling of absurdity. For example, in scene VII, after the Smiths and the Martins have exchanged a few platitudes and definitely seem uncomfortable in each other's presence, Mr Smith utters: "Ah, la la la la"16 (Ionesco, 1954: 64). Mr Martin then asks him: "Vous avez du chagrin ?" (Ionesco, 1954: 64), which was translated as "Don't you feel well?" (Allen, 1958: 20). In the source text, the rather crude reply to this question comes from Mrs Smith: "Non, il s'emmerde"17 (Ionesco, 1954: 64). This sentence would be very likely to be interpreted by a source reader in terms of its figurative meaning, "he is bored out of his skull", and does not render the scatological component of the verb "s'emmerder". It must be noted that this expression is one of the many scatological references used by Ionesco throughout the play, because he considered these to be a source of laughter (Jacquart, 1993a: 147).

In the target text, Mrs Smith's reply reads as follows: "No, he's wet his pants" (Allen, 1958: 20). Although it is indeed a ludicrous statement and provides a pertly logical answer to Mr Martin's question, once again it does not echo Ionesco's scatological vein and does not really render the abrupt drop in language register of the source text. "He is bored shitless", on the other hand, is both scatological and shocking.

In a situation such as this one, where retaining both the drop in language register and the scatological reference may represent a problem, it would be up to the translator to decide which of the two issues should be given priority, based on the extent to which each contributes to conveying the absurd.

From an extratextual point of view, various instances of problematic translation have been identified. Firstly, the estranged $\mathrm{Mr}$ and Mrs Martin attempt to find out why they look so familiar to each other and start talking about the time they took the train from Manchester. In the target

16 "Oh dear, oh dear, oh dear" (Author's translation).

17 "He is bored out of his skull" or "he is bored shitless" (this possible translation has the advantage of echoing Ionesco's vein). 
text, Mr Martin says: "Madam, I took the 8:30 morning train which arrives in London at 4:45" (Allen, 1958: 15), which does not seem to present any problems out of context. However, in the source text, Mr Martin uses a typically English structure in order to express these times: "J'ai pris le train d'une demie après huit le matin, qui arrive à Londres à un quart avant cinq, madame" (Ionesco, 1954: 54). This French sentence includes a literal translation of the way in which a speaker of English would have said: "half past eight in the morning" and "quarter to five". ${ }^{18}$ This creates a surprising and comical effect (Jacquart, 1993a: 142). The English translation therefore does not render this effect at all. In the target text, the English character utters a statement in French, which is based on an English idiom. Here, the translation fails to render the comical and possibly confusing effect created by the word-for-word translation of an idiomatic English expression into French.

The following suggestion: "Madam, I took the train of eight hours and half of the morning, which arrives in London at five hours minus the quarter", is more appropriate in the sense that it renders the aforementioned effect in reverse. However, it would not make sense to have Mr Martin, who is English, utter an English sentence which was translated word-for-word from a French idiomatic expression. Although this may be acceptable in the realm of the Absurd, in which logic is set aside, the above suggestion would also fail to convey the same effect as the source text to English-speaking readers.

The issue therefore is how to convey the same comical effect while respecting the interlinguistic word play. This might only be possible by changing the character's nationality. If Mr Martin became Monsieur Martin and acquired the French nationality, for example, he could then utter the suggested phrase in English ("Madam, I took the train of eight hours and half of the morning, which arrives in London at five hours minus the quarter"), based on the French expression "le train de huit heures et demie du matin, qui arrive à Londres à cinq heures moins le quart". In this way, one would obtain the same foreignising effect as in the source text.

Again, one might argue that the problems highlighted above do not in any way put the conveying of the philosophical message in jeopardy, nor the general effect that the translation may have on the target reader, except in the case of Mr Martin's utterance about the time at which he took the train. However, we have already established that La Cantatrice Chauve does not only belong to the philosophical genre, but also, as a play, to the literary genre. The above considerations, although not directly relevant to the philosophical dimension of the play, may nonetheless contribute to the overall quality of the translation, accuracy being one of the fundamental criteria of quality in translation.

Secondly, further in the scene, Mr Martin utters "La maison d'un Anglais est son vrai palais" (Ionesco, 1954: 94). This sentence, although in French, is reminiscent of the English saying "An Englishman's home is his castle". This creates surprise as this proverb was translated literally

18Literally translated, French speakers would tell the time by saying, not "half past" or "quarter to", but "and a half" or "minus the quarter". 
and does not evoke any French proverb which might have a similar meaning. Therefore, readers of the original French who are not familiar with the English expression - which, it can be assumed, might be a majority as they are supposed to be native speakers of the source language - are unlikely to identify it as such, which will therefore put this sentence at the same level of absurdity as the preceding example would. This effect should therefore be rendered in the target text, which is not the case. Indeed, the target text reads as follows: "An Englishman's home is truly his castle" (Allen, 1958: 38), which only differs from the original saying by the addition of the adverb "truly". The target reader will thus easily recognise the proverb despite the addition, which is unlikely to recreate the confusion and feeling of absurdity conveyed by the source text. I therefore suggest that the target text base itself on a French proverb translated into English in order to achieve the same effect on the reader as the source text. Preferably, and if possible, the French proverb should have a meaning similar to the English one. It so happens that "An Englishman's home is his castle" has a French equivalent which is "Charbonnier est maitre chez lui", which could be literally translated as "The coalman is the master in his own home". ${ }^{19}$ However, it may be argued that the actual meaning of the proverb is of little importance within the text, as there is hardly any semantic cohesion or coherence throughout the play, which is one of the characteristics of Absurdist theatre in general, and of La Cantatrice Chauve specifically (Jacquart, 1993b: 10).

The last extratextual issue in terms of translation is the nationality of the characters.

In Absurd drama, it is often difficult to sympathise with the characters, as their motives are hidden and we thus find it difficult to understand their actions (Hinchliffe, 1977: 5).

Contrary to traditional theatre, it is actually a prerequisite of the Theatre of the Absurd that the audience should find it difficult to identify with the characters, because the Theatre of the Absurd aims at expressing the fact that our society is disintegrating, and that the relationships between people are losing their substance - replaced with clichés, commonalities or even hostility and aggression. This cannot be achieved if the audience identifies with the characters. If the audience identified with the characters, it would mean that they accept their point of view, and therefore see the world through their eyes, and feel their emotions - in other words, the audience would sympathise with the characters (Esslin, 1980: 410).

This is why characters in the Theatre of the Absurd do not seem to have any explicable motives, which in turn makes their actions incomprehensible. According to Esslin:

(W)ith such characters it is almost impossible to identify; the more mysterious their action and their nature, the less human the characters become, the more difficult it is to be carried away into seeing the world from their point of view (1980: 411).

19 Author's translation. 
It is therefore essential that this non-relationship be retained in the target text. This can be achieved by the dynamic rendition in the target language of the absurd dialogues and situations.

However, this does not mean that the target text must absolutely stick to all of the characters' characteristics, like their nationality. In the original French version, $\mathrm{Mr}$ and Mrs Smith, as well as all of the other characters, are English. As Emmanuel Jacquart states in his preface to La Cantatrice Chauve, this is due to the author of the play, Eugène Ionesco, finding inspiration for the play while teaching himself English. Inspired by the accumulation of clichés and commonplace statements used in the curriculum of the language course he followed, Ionesco decided to communicate the essential truths he had found in the method to his contemporaries (1993b: 8-9). It therefore seems that the characters' names and nationality are the products of a coincidence. Had Ionesco intended to learn German, the characters may have been German and called $\mathrm{Mr}$ and Mrs Schmidt.

However, nationality is a concept which is heavy with cultural connotations. It could be argued that, although this was not the author's intention, the animosity between the French and English - which is widely recognised as historical, though debatable nowadays - may have influenced the way the audience perceived the play when it was first staged, and may still do so. On top of the audience being exposed to the purposelessness of human existence, and its resulting anxiety, another element may have come into play, which may have emphasised the comical aspect of the play: the fact that the audience was French, and the characters unmistakably English. The former may therefore have relished the fact that the absurd elements, whether situational or dialogue-related, were being conveyed in a context where it may have been considered as stereotypically English.

Therefore, although the nationality of the characters does not seem to be essential as far as conveying the existentialist angst of the Theatre of the Absurd, one cannot deny that it is an element that can provoke a specific reaction on the part of the audience, like the one mentioned above. This reaction may or may not come in the way of an Absurdist play's original purpose. A French audience may see in La Cantatrice Chauve a satire of English ways.

Ionesco was actually aware of that risk, as he decided against such titles as "L'Heure anglaise", "Big Ben Folies" and "Une heure d'anglais", for fear the play should be interpreted as a satire of the English (Jacquart, 1993b: 11). It could however be argued that such a surprising title as La Cantatrice Chauve does not necessarily exclude such a satire. If this is the case, one could argue that an English translation retaining the characters' nationality and the typical English setting as announced at the start of the play, as Allen's translation does (1958: 8), may lead an English audience to view it as a satire too, and depending on their frame of mind they might find it amusing or offensive. Whether from a French or an English point of view, the nationality of the characters gives rise to considerations, positive, negative or even neutral, which have the potential to distract the audience from the message the play is set to convey. As Ionesco mentioned,

[1]a Cantatrice Chauve "la pièce n'est pas une parodie de thêâtre 
de boulevard, une critique des clichés et du comportement automatique des êtres, de la petite bourgeoisie ou une tentative de destruction du théâtre (Jacquart, 1993b: 18).

This leads to the following question: How can the element of nationality be handled in the translation so as to minimise, if not totally avoid, what we might call a 'culturally motivated' reaction?

First of all, one could suggest that the English nationality of the characters be changed to another one, for example German. Ionesco says that his characters are supposed to represent

une sorte de petite-bourgeoisie universelle, le petit-bourgeois étant l'homme des idées reçues, des slogans, le conformiste de partout...

(Jacquart, 1993b: 19-20).

The word "universelle" used in this statement indicates that the nationality of the characters is not the most essential of all the meaning-creating elements of the play, and that what actually matters is the fact that the characters are from a bourgeois (middle-class) background, which exists in most societies regardless of country, language or culture.

The introduction of German characters in the translation may be more likely to create the same impression among target reader as a French audience would have had of the source text.

This idea can be effectively applied to the very first didascalia in the target text, as it is characterised by numerous occurrences of the adjective of nationality, "English".

In a theatre text, didascalia are stage directions, an essential feature of the written play, because they allow the reader to visualise what the spectators of the performance would see on stage. In the case of the Theatre of the Absurd, and especially in Ionesco's work, it may be argued that the function of the didascalia is just as important as the main text, if sometimes not more so, for the reader to understand what is going on as most of the time it's completely absurd.

A middle-class English interior, with English armchairs. An English evening.

Mr Smith, an Englishman, seated in his English armchair and wearing English slippers, is smoking his English pipe and reading an English newspaper, near an English fire. He is wearing English spectacles and a small gray English moustache. Beside him, in another English armchair, Mrs Smith, an Englishwoman, is darning some English socks. A long moment of English silence. The English clock strikes 17 English strokes (Allen, 1958: 8).

A translation applying the suggestion made earlier may read as follows:

Bourgeois German home, with German armchairs. German evening. M. Meyer, German, sitting in a German armchair and wearing German slippers, smokes his German pipe and reads a German newspaper, next to a German fire. He is wearing German spectacles and a bushy grey German moustache. Next to him, Mrs Meyer is sitting in another German armchair, darning German socks. A long German silence. The cuckoo clock strikes seventeen 
German times. ${ }^{20}$

Although the translation does not change considerably, English-speaking readers may get an impression more similar to the one experienced by the French audience than if they were reading about or watching characters of their own nationality and cultural background. Moreover, the suggested translation may evoke a scene in a comfortable, bourgeois Bavarian home, thus conveying Ionesco's original intention, that his characters should be middle-class.

However, changing the English nationality to another does not entirely solve the problem of the translation appearing as a satire, even though it may not be a satire of the English anymore. A reader of the target text may be justified in interpreting the new translation suggested above as a satire of the German way of life. It is, however, not the purpose of La Cantatrice Chauve to poke fun at a specific ethnic group or culture, as mentioned earlier on in this section. Nevertheless, a French-speaking reader of the source text would also have good reasons to interpret the play as a satire, as many of the ingredients of a satire are present.

In this case, the above considerations, once applied to the target text, may indeed help improve the source text. ${ }^{21}$

Can one therefore conceive of a translation which does not render nationality at all, in order to avoid the reader misinterpreting the meaning of the play? This may be possible, considering that the nationality of the characters does not create essential meaning. The characters happen to be English solely because Ionesco was inspired to write this play while teaching himself English. Suppressing any mention of nationality has, nevertheless, implications: it implies doing away with the first and last names of the characters, so that they cannot be related to any ethnic group in particular. The characters could be referred by letter, number, or any appellation which is unlikely to bear connotation to a specific nationality or culture. Each of these suggestions has the double advantage of preventing the establishment of a link with a specific culture as well as denying the characters their individuality, which reinforces the Absurdist theme of disintegration of society and human relationships mentioned earlier on.

Although this paper focuses on the written form of the play, it may be interesting to look into the changes in mise-en-scène which would have to be made for the stage performance of the target text as opposed to a performance of the original. If the didascalia in the source text is translated by replacing the English nationality with German for the reasons already been mentioned, the director of the play will have to think of a mise-en-scène where the décor and the character's clothing are stereotypically German (which could encompass quite a wide range of possibilities). On the other hand, if the same didascalia is translated

20 Author's translation.

21 Here, it must be highlighted that should the translator decide to change the nationality of the characters with the intention to domesticate the translation further, all other cultural references (e.g. the "false" proverbs and aphorisms discussed in the second and first parts) would have to follow suit. This article is not suggesting that only the characters' nationality should be changed. 
suppressing any mention of nationality and culture, the various semiotic elements of the mise-en-scène will have to be kept as neutral as possible, so as to avoid any possible association with a certain culture or nationality. This alone would be a difficult exercise, as neutrality itself could be considered a notion related to culture.

However, if the nationality of the characters is changed or removed in order to suit the needs of the translation, one runs the risk of not projecting the author's world, which is, according to Esslin, also part of what the Theatre of the Absurd is based on (1980: 403). Nevertheless, one may wonder whether it is indeed essential, as the audience is likely unaware of the context in which Ionesco created the play, that is to say, while trying to teach himself English.

This is indeed incidental and, I believe, does not carry as much weight as the author's intention. Indeed, the author's intention is one of the three aspects of the author's attitude, implicit or explicit, towards the "treatment of the subject matter" (Hervey \& Higgins, 2002: 59). As such, the author's intention is particularly relevant to the translation of La Cantatrice Chauve since, as was previously established in this paper, Ionesco did have an intention, albeit not an ideological one, while writing his play.

The issue of the characters' nationality in La Cantatrice Chauve will lead the translator to consider the matter of cultural difference between French and English, not only at linguistic level, but also at the level of the absurd. The issue of linguistic dynamic equivalence between the source and the target text has been dealt with in the second section of this paper. However, this is not the only aspect of the translation on which culture has an influence.

Indeed, what about the notion of absurdity? Various taxonomies of translation methods have been designed in order to assist the translator in dealing with the issue of culture in translation. For example, Hervey \& Higgins offer various translation methods, such as exoticism, cultural transplantation, calque, cultural borrowing and communicative translation (2002: 33-36). However, these methods only seem relevant to general translating situations, and do not really shed any light on the issue of translating the absurd from one culture into another. Translating La Cantatrice Chauve - and by extension any other Absurdist play - should cause the translator to ask himself what it is that the source culture within which the text was created considers as absurd, and whether these indicators of the absurd would be interpreted in the same manner in the target culture.

The intertwined history and physical closeness of the French and the English may lead one to assume that they have a lot in common in terms of culture and therefore in terms of what they respectively consider as absurd. This is what Allen seems to have thought, as The Bald Soprano does not distance itself from the French original in terms of the elements that convey the feeling of absurdity, i.e. the discrepancy between the dialogues and the situations, and the style evoking a growing tension between the characters, especially in Scene XI.

Admittedly, a fireman going door-to-door looking for a fire to extinguish (Scene VIII) - although he is not allowed to put out a fire at priests' houses - and a couple who act as if they were meeting for the first time although 
they have been married for some time (Scene IV) are elements of the plot which certainly defy reason for the French and the English alike.

But this is not to say that the absurd situations depicted in La Cantatrice Chauve would be seen as such within a different culture.

\section{Conclusion}

This article concerns itself with the evaluation of an English translation of the Absurdist play, La Cantatrice Chauve, by Eugène Ionesco.

This evaluation shows that, in the way it deals with the relevant textual, intertextual and extratextual elements of the play, Allen's translation is successful in conveying the absurd. It may, however, require some minor adjustments at textual level, as it presents a few inaccuracies, but these issues do not have negative repercussions as far as the creation of a feeling of absurdity is concerned, which, according to the discussion in the first section, is a tool that Ionesco relies on in order to convey his philosophical message, as do Absurdist authors in general. Nevertheless, some alternative suggestions have been made with a view to enhancing the translation in terms of its expression of the breakdown of society and meaninglessness of human existence. Mostly, these suggestions point out the fact that the relevant extracts, although accurately translated, may have benefited from further domestication.

This article also points out that the translation of La Cantatrice Chauve, as well as the translation of Absurdist plays as a whole, cannot be approached at textual or linguistic level alone, and requires knowledge of the general purpose of the Theatre of the Absurd, as well as an awareness of the cultural implications surrounding the notion of Absurd.

In the broader context of a general study of the translation of the Theatre of the Absurd, the conclusions of this paper may be considered as helpful, as they may be relevant to designing translation methodology for written plays. This methodology could also be used as a basis for staging the translated play, which would imply the consideration of the various semiotic elements of the mise-en-scène.

\section{Bibliography}

Browning, R. My Last Duchess. (In Pettigrew, J., ed. Robert Browning. The Poems. Vol I. 1981). Harmondsworth \& New York: Penguin Books. p.349-350.

Chesterman, A. \& Wagner, E. 2002. Can theory help translators? Manchester: St Jerome

Esslin, M. 1980. The Theatre of the Absurd. Revised and enlarged edition. Harmondsworth: Pelican Books

Fawcett, P. 1997. Translation and Language. Manchester: St Jerome

Hervey, S. \& Higgins, I. 2002. Thinking French Translation. A course in translation method French to English. $2^{\text {nd }}$ edition. New York: Routledge.

Hinchliffe, A.P. 1977. The Absurd. Series: The Critical Idiom. Methuen \& Co: London 
Ionesco, E. 1954. La Cantatrice Chauve. Saint-Amends: Gallimard Ionesco, E. 1958. The Bald Soprano. New York: Grove Press.

Jacquart, E. 1993a. Dossier. (In Ionesco, E., La Cantatrice Chauve. SaintAmand: Gallimard)

Jacquart, E. 1993b. Préface. (In Ionesco, E., La Cantatrice Chauve. SaintAmand: Gallimard

Mateo, M. 1995. Translation strategies and the reception of drama performances: a mutual influence. (In Snell-Hornby, M. \& Jettmarová \& Z. Kaindl, K., eds. Translation as intercultural communication. Prague: Benjamins).

Munday, J. Translation Projects. http://www.routledge.com/textbooks / 041528306X/pdf/Translation_Projects.pdf_[Date of access: 10 March 2007]

Venuti, L. 1995. The Translator's Invisibility. A history of translation. London: Routledge.

Vermeer, H.J. 2004. Skopos and commission in translational action. (In Venuti, L., ed. The Translation Studies Reader. $2^{\text {nd }}$ edition. London; New York: Routledge 